\title{
Technical change and financial efficiency: Plowing - rotary tractors in Ukraine
}

\author{
Vladimir Kyurchev \\ Deptartament of Mashynovykorystannya in Agroculture Tavricesciy State Agrotechnical University, Melitopol, Ukraine
}

\section{Email address:}

agro2014@meta.ua

\section{To cite this article:}

Vladimir Kyurchev. Technical Change and Financial Efficiency: Plowing - Rotary Tractors in Ukraine. Journal of Finance and Accounting. Special Issue: Synergy of Accounting, Finance and Management in Chaotic Environment. Vol. 2, No. 6-1, 2014, pp. 8-12. doi: $10.11648 /$ j.jfa.s.2014020601.12

\begin{abstract}
Methodological tool of total costs calculation using machine-tractor aggregates on the basis of plowing and cultivating tractors has been described. Financial effectiveness evaluation of technological changes introduction while using plowing and cultivating tractors has been conducted. Financial effectiveness of using tractor aggregates used in Ukrainian farms has also been analyzed.
\end{abstract}

Keywords: Economic Efficiency, Cost, Cost Management, Tractor, Financial Evaluation

\section{Introduction}

Main energy tool in agricultural production in any country was and will remain the tractor. Therefore, Ukraine, where agriculture is regarded as the locomotive of the economy must have a clear tractor policy, institutional framework that should be technical and economic efficiency of using cultivating and weeding tractors.

Do not always using the standard technique provides the desired efficiency of agricultural production. The use of machine complexes on the basis of all-purpose domestic energy resource with advanced technological properties may provide more efficient management and the overall financial results of the company. The possibilities should be considered when frontal toolbar (especially energy-intensive) has not provided the desired effect. Incorrect aggregation, instead of the desired weight transfer hitch of the tractor has not given the desired unloading, as the result they lost control and stability of motion.

\section{Literature Review}

When working with agricultural aggregates stability and controllability is considered as an important performance indicators, which include the ability of its links to counteract the influence of external disturbing forces. They (when considered in the horizontal plane) directly linked to a range of operational parameters that determine ultimately the quality, material cost and complexity of performing farming operations.

Binswanger assembled the studies and presented findings in a way which makes them comparable across agroclimatic areas [1]. Economic aspects of agrarian reform under the new society have been investigated by Mangahas [2]. The problems of risk management in agriculture study Ramaswami, B; Shamiika, R; Chopra, S.D [3]. Financial of management agricultural business described in financial liberalization [4], financial reports [5], default [6], economic conditions of agricultural labour households [7], agricultural credit utilization pattern and its repayment [8] aspects.

Yotopoulos proposed a micro-analytic approach «From stock to flow capital inputs for agricultural production functions» [9]. The development of mathematical models of planting outfit on the basis of arable-1 / $t$ tractor have been studied by Ukrainian scientists [10], [11], [12], [13]. The main aim of these studies was to establish the possibility of the asymmetric aggregation units on sowing and inter-row cultivation of tilled crops.

The structure of sown areas of Ukrainian crops on farms, by 11 July 2013 is presented in table 1 . 
Table 1. The structure of sown areas of Ukrainian crops on farms, by 11 July 2013, thousands of hectares

\begin{tabular}{|c|c|c|c|c|c|c|c|}
\hline Structure & 2012 & 2013 & growth & Structure & 2012 & 2013 & growth \\
\hline Tilled soil availability & 20975,5 & 21041,5 & 66,0 & sorghum & 140,3 & 124,1 & $-16,2$ \\
\hline Stale & 2052,4 & 1730,2 & $-322,2$ & Other grain $* *$ & 5,9 & 1,0 & $-4,9$ \\
\hline Total sowing area & 19175,7 & 19601,0 & 425,3 & Technical- total & 6408,1 & 6519,8 & 111,7 \\
\hline Grain crops, total & 11566,0 & 12011,9 & 445,9 & include: sugar beet & 413,4 & 231,4 & $-182,0$ \\
\hline Winter crops on grain & 5110,2 & 6058,4 & 948,2 & sunflower & 3913,3 & 3876,7 & $-36,6$ \\
\hline include: wheat and triticale & 4361,3 & 5045,9 & 684,6 & Winter rape & 463,9 & 947,2 & 483,3 \\
\hline rye & 218,0 & 202,3 & $-15,8$ & Spring rape & 94,4 & 48,1 & $-46,3$ \\
\hline barley & 530,9 & 810,3 & 279,4 & soya & 1376,5 & 1273,8 & $-102,7$ \\
\hline Other winter crops* & 0,0 & 0,0 & 0,0 & long-fibred flax & 2,2 & 1,5 & $-0,7$ \\
\hline Spring grain and grain legumes & 6455,8 & 5953,5 & $-502,3$ & oily flax & 51,1 & 43,8 & $-7,3$ \\
\hline include: barley & 1518,6 & 1207,9 & $-310,7$ & Other technical*** & 93,3 & 97,3 & 4,0 \\
\hline wheat & 177,5 & 103,7 & $-73,8$ & potato and vegetables- total & 97,3 & 77,8 & $-19,5$ \\
\hline oats & 188,8 & 132,9 & $-55,9$ & Include potato & 40,1 & 29,8 & $-10,3$ \\
\hline Grain legumes- total & 269,1 & 236,0 & $-33,1$ & vegetables, melon field & 57,2 & 48,0 & $-9,2$ \\
\hline pea & 196,8 & 170,2 & $-26,6$ & Fodder,-total & 1104,3 & 991,5 & $-112,8$ \\
\hline buckwheat & 251,7 & 142,3 & $-109,4$ & include maize on silo & 366,8 & 334,7 & $-32,1$ \\
\hline millet & 139,6 & 62,5 & $-77,1$ & Perennial grass & 483,2 & 443,3 & $-39,9$ \\
\hline rice & 25,5 & 24,2 & $-1,3$ & Annual grass & 231,6 & 196,7 & $-34,9$ \\
\hline dent corn on grain & 3738,8 & 3918,9 & 180,1 & Other forage $* * * *$ & 22,7 & 16,8 & $-5,9$ \\
\hline
\end{tabular}

* winter vetch;

** mix corn, vetch and vicious for grain, rank, lupine and others.

*** crown flax, tobacco, uterine crops and seed crops, mustard, oil-bearing crops, California Bluebell, red, castor bean, Nigella, poppy oil, and others.

**** fodder beet, sugar beet forage for livestock, fodder melons, broad beans, lupines green mass, cabbage, turnip, and other.

\section{The Methodology and Model}

One of the main indicators of using agricultural machinery efficiency is total expenses (TE) per unit of work performed. Evaluation agricultural engineering in the test phase, they consist of the amount of direct operating expenses (OE) and multiplied by bet soft loan NBU (IR $=20 \%$ ) specific investment (SI):

$$
\mathrm{TE}=\mathrm{OE}+\mathrm{IR} \cdot \mathrm{SI} / 100
$$

In turn, the direct operating cost is the sum of the following components:

$$
\mathrm{OE}=3+\mathrm{A}+\mathrm{R}+\mathrm{F}+\mathrm{M}+\mathrm{E}
$$

where W - wages of the staff; A - costs of amortization; P expenses for repairs and maintenance; $\mathrm{F}$ - the cost of fuel and lubricants; M - the cost of auxiliary materials; E - on installation costs, storage and insurance of the equipment

The salary of each member of the staff of a particular unit is determined by the formula:

$$
\mathrm{W}=\frac{\sum_{\mathrm{i}=1}^{\mathrm{n}} \mathrm{L}_{\mathrm{i}} \cdot \mathrm{r}_{\mathrm{i}} \cdot \mathrm{k}_{\text {д }} \cdot \mathrm{k}_{\mathrm{i}}}{\mathrm{WE}},
$$

where $\mathrm{Li}$ is the number of $\mathrm{i}$-th category of personnel to be employed for execution of the main process, maintenance and repair of machines, people; ri is the hourly rate of pay, $\mathrm{UAH} /$ person $\cdot \mathrm{h} ; \mathrm{k}_{\mathrm{д}}$ is the coefficient that takes into account additional payments to hourly rate for the products, proficiency, work experience, etc.; ki is the coefficient of accruals for wages (pension Fund, social insurance, employment assistance Fund); WE - the performance of the machine for hours of shift time, a unit operating time/hours

Machines depreciation expenses are calculated according to the formula:

$$
\mathrm{A}=\frac{\mathrm{B} \cdot \mathrm{a}}{\mathrm{WE} \cdot \mathrm{TC}}
$$

where $\mathrm{B}$ is the carrying amount of the machine; and the ratio of machines depreciation; TC - zonal annual load for machines.

The carrying cost of the machine is determined as follows:

$$
\mathrm{B}=\mathrm{EP} \cdot \mathrm{ke},
$$

where EP is the machine price, hrn; ке - conversion rates of the machine in the carrying amount; $\mathrm{\kappa e}=1,1$ is for machines that do not require installation work or additional assemblies directly on site; ке $=1,2$ is if require works mentioned above.

The ratio of depreciation of the machine often calculated using the straight-line method, i.e.:

$$
\mathrm{a}=1 / \mathrm{n},
$$

where $\mathrm{n}$ is the life of the machine in years.

The cost of capital and current repairs and maintenance were determined by the formula:

$$
P=\frac{B \cdot\left(r_{T}+r_{K}\right)}{W_{\text {ек }} \cdot T_{H}},
$$

where $r_{T}$ is the ratio of payments on current repairs and maintenance; $r_{K}$ is the coefficient of deductions for capital repairs; $T_{H}$ the normative annual loading machine, including; Wек the performance of the new machine for 1 hour of operating time, unit groundwork/h.

$$
\mathrm{F}=\mathrm{q} \cdot \mathrm{kp} \cdot \mathrm{Pp}
$$


where $\mathrm{q}$ is the specific fuel consumption, $\mathrm{kg} / \mathrm{unit}$ running hours; $\mathrm{Pp}$ is the price of one kilogram of fuel, $\mathrm{hrn}$. $/ \mathrm{kg}$; $\mathrm{Pp}$ is the coefficient taking into account the cost of lubricants.

The cost of assistive technological products are calculated according to the formula:

$$
\mathrm{E}=\sum \mathrm{h}_{\mathrm{i}} \cdot \mathrm{Pp},
$$

where hi is the unit cost of the i-type of the process material; $\mathrm{CG}$ and the unit price of the i-process material, hrn./kg (m, pieces).

Storage costs, insurance, and installation of machines (M) in hrn per unit of operating time is calculated as follows:

$$
\mathrm{M}=\frac{\sum_{\mathrm{i}=1}^{\mathrm{n}} 3_{\text {пі }} \cdot \mathrm{r}_{\mathrm{i}} \cdot \mathrm{k}_{\mathrm{i}}+\mathrm{Cm}+\mathrm{S}_{3 \mathrm{CM}}}{\mathrm{W}_{\text {ек }} \cdot \mathrm{T}_{3}},
$$

where 3-ni is the labor costs of the category of workers on the assembly and installation of equipment, person-hours; $\mathrm{Cm}$ is the cost of the materials that are used in regeneration and installation of machines, hrn.; $\mathrm{S}_{3 \mathrm{CM}}$ the annual costs of storage and insurance of machinery, RS.

Specific investments are calculated by the following formula:

$$
\mathrm{SI}=\frac{\mathrm{B}+\mathrm{K}_{\text {Буд }}}{\mathrm{W}_{\mathrm{eк}} \cdot \mathrm{T}_{3}},
$$

where is carrying amount of construction unit for machine operation, (entered into the formula if there is a difference in the volume of construction of the new and basic machine), hrn.

The second important indicator of the efficiency of a particular unit is unit labor costs (W). To find out, use the formula:

$$
\mathrm{W}=\frac{\sum_{\mathrm{i=1}}^{\mathrm{n}} \mathrm{L}_{\mathrm{i}}}{\mathrm{W}_{\mathrm{e \kappa}}},
$$

The annual economic effect (EEa) from the operation of any new machine - tractor unit is determined by the formula:

$$
\mathrm{EEa}=(\mathrm{TEn}-\mathrm{TEo})+\mathrm{EQa},
$$

where the TEn, TEo is the total expenses of the implementation of the annual volume of work in the household, respectively, the base and the new MTA, hrn./ unit of running hours; EQa is annual economic effect obtained by changing the quantity and quality of products in the operation of the new MTA, hrn./unit running hours.

Annual savings in the unit cost of labour from the new MTA (Sprk) is calculated by the formula:

$$
\mathrm{Wa}=\mathrm{Wn}-\mathrm{Wo}
$$

where $\mathrm{Wn}$, Wo the annual unit costs of labor, respectively, by a new and basic machine-tractor units, person-hours.
For comparative analysis we will consider a new combined and wide-units on the main plowing and cultivating tractors.

It is also should be mentioned that each of the developed compared units is served by one mechanic. Therefore, in the above expression (3) $\mathrm{i}=\mathrm{n}=\mathrm{L}=1$. In addition, to simplify the calculations without significant effect on their reliability, accruals for salaries and allowances for proficiency, work experience, etc. in all of the compared variants did not take into account. That is $\mathrm{ki}=\mathrm{kd}=1$. Moreover, they believed that $\mathrm{M}=\mathrm{KBUD}=0$, a $\mathrm{k} \Pi=1,03$.

Calculations of the total expenses of using the machine-tractor units on the basis of plowing and cultivating tractors on the obtained expression was carried out in a software environment Microsoft Office Excel. The portion of the source data was taken from the results of operational and technological assessment of the MTA, and the rest from literary sources.

\section{Results and Discussions}

The determining factor in assessing the effectiveness of the use of arable-1 / t tractor is its high technological versatility. Towards the confirmation of this postulate, consider the following fact.

\begin{tabular}{|c|c|c|c|c|}
\hline Farmer & Area (Region) & Crop & $\begin{array}{l}\text { Area } \\
\text {, ha }\end{array}$ & Tractors \\
\hline \multirow{4}{*}{ M.P.Yatsun } & \multirow{4}{*}{ Cherkaska. } & \multirow{4}{*}{ sunflower } & \multirow{4}{*}{40} & 1. $\mathrm{T}-150 \mathrm{~K}$ \\
\hline & & & & 2. $\mathrm{T}-150$ \\
\hline & & & & 3. MTZ-80 \\
\hline & & & & 4 «John Deere» \\
\hline \multirow{5}{*}{ A.G.Ischenko } & \multirow{6}{*}{ Poltavska } & \multirow{5}{*}{ corn } & \multirow{6}{*}{319} & 1. « Case $8920 »$ \\
\hline & & & & 2. « Case STX 500» \\
\hline & & & & 3. « Case 9390» \\
\hline & & & & 4. « Case 7250» \\
\hline & & & & 5. « Case MX 285» \\
\hline \multirow{3}{*}{ L.M.Fesyk } & & \multirow{3}{*}{$\begin{array}{l}\text { Spring } \\
\text { barely }\end{array}$} & & 1. K-700 \\
\hline & \multirow[t]{2}{*}{ Chernigivska. } & & \multirow[t]{2}{*}{114} & $\begin{array}{l}\text { 2. « New Holland» } \\
\text { 3. MTZ - } 80\end{array}$ \\
\hline & & & & 4. $\mathrm{T}-150$ \\
\hline \multirow{9}{*}{ D.Yu.Vasyliev } & \multirow{9}{*}{ Kirovogradska. } & \multirow{4}{*}{ sunflower } & \multirow{4}{*}{90} & 1. « Case » \\
\hline & & & & 2. $\mathrm{T}-150$ \\
\hline & & & & 3. JUMZ -82 \\
\hline & & & & 4. MTZ - 1025 \\
\hline & & \multirow{5}{*}{ Sugar beat } & \multirow{5}{*}{150} & 1. $\mathrm{T}-150$ \\
\hline & & & & 2. « Case » \\
\hline & & & & 3. MTZ - 100 \\
\hline & & & & 4. $\mathrm{T}-70$ \\
\hline & & & & 5. MTZ -82 \\
\hline \multirow{3}{*}{ V.V.Леган } & \multirow{3}{*}{ Khmelnytska. } & \multirow{3}{*}{ Sugar beat } & \multirow{3}{*}{179} & 1. « Case » \\
\hline & & & & 2. MTZ -82 \\
\hline & & & & 3. « John Deere » \\
\hline
\end{tabular}

Analysis of their technology showed that the majority of presents advanced farmers on the cultivation of only one culture area of from 40 to 300 ha are using 4-5 different energy funds (table. 2). Moreover, most of them are of foreign origin.

Table 2. Complexes tractors, used by farmers for crop production

For further analysis, let us take energotechnological complex of the farmer A.G. Ishchenko from the Poltava region, who is built on the basis of only foreign tractors "Case", and 
let us compare it with similar complex, based on domestic series tractor HTZ-160, namely, the HTZ-16131 (Table. 3).

As the main evaluation criterion was adopted total cost for growing corn on the square 319 ha on the implementation of the technical measures, which are implemented by the farmer A.G. Ishchenko (Table. 2).
Aggregate and other expenses that are used to assess personally complexes were calculated by the above method. Analysis of the calculations showed that the application of complex A.G. Ishchenko workload of five tractors in the cultivation of maize in the area of 319 ha is 315 hours on average one power tool accounts for 63 hours

Table 3. Technological cart for carrying out agricultural procedures aimed at growing corn

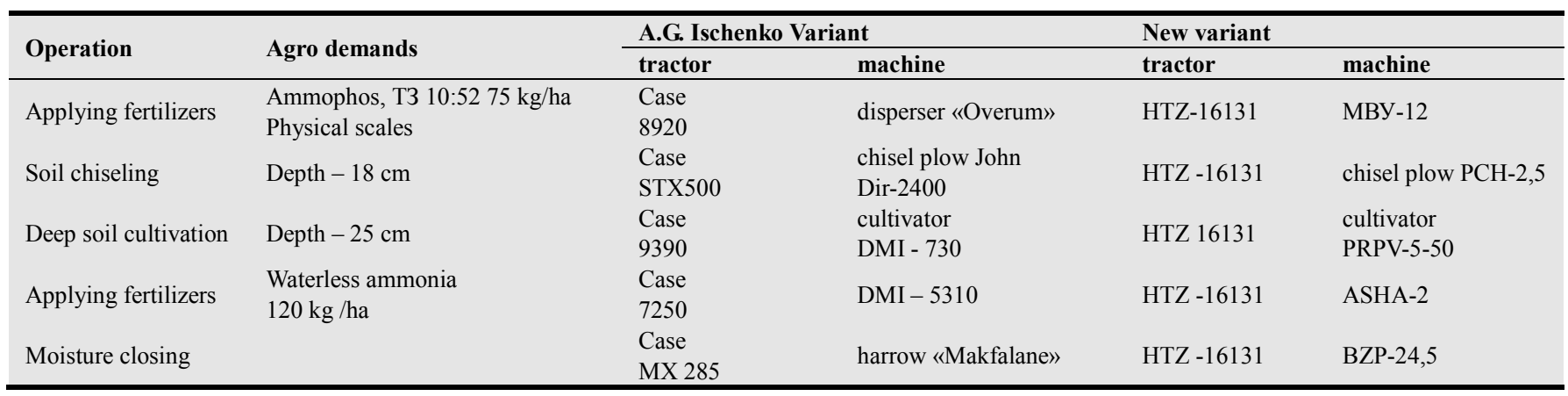

Total labor costs when implementing complex A.G. Ishchenko will be 415 people-hours, while when applying domestic - 630 person-hours Is 1.5 times more. But it is important that the duration of execution of the technological operations complex machines on the basis of HTZ-16131 does not exceed agro acceptable terms.

According to all other indicators has the advantage of domestic complex. So, the cost of spent fuel and lubricants means it has less than 2.7 times, operating costs less than 1.7 times, capital (or according to DSTU 4397:2005 - investment) investment 6 times, and finally, total expenditures - 2.1 times.

Comparative evaluation of the implementation of a number of technological operations units on the basis of plowing and cultivating series of tractor HTZ-160 and similar MTA based on serial power tools (table 4) shows that the use of new composite and wide machine-tractor units allows to reduce the total cost of $4.5 \ldots 40,0 \%$.

Table 4. Comparative techno-economic assessment of combined units on the basis of plowing and cultivating tractor

\begin{tabular}{|c|c|c|c|}
\hline $\begin{array}{l}\text { MTA on the basis of plowing and } \\
\text { cultivating tractor }\end{array}$ & MTA Structure & Comparative basis & Shortage of total expenses, \% \\
\hline Harvesting and shelling & HTZ-160 + SHVN-6 + BDN-3 & $\begin{array}{l}\text { SK-5 + SHVN -6 } \\
\text { HTZ }-170+\text { BDT-7 }\end{array}$ & 32,9 \\
\hline Plowing and blending & $\begin{array}{l}\text { HTZ }-160+ \\
\text { PRR-1,5 + PLN-5-35 }\end{array}$ & $\begin{array}{l}\text { HTZ }-170+\text { BDT }-7 \\
\text { HTZ }-170+\text { PLN }-5-35\end{array}$ & 33,3 \\
\hline Plowing & $\begin{array}{l}\text { HTZ }-160+ \\
\text { PLN }-2-35+\text { PLN }-4-35\end{array}$ & HTZ - $170+$ PLN $-6-35$ & 4,5 \\
\hline Disking and chisel & HTZ -160 + BDN -3 + PCH-2,5 & $\begin{array}{l}\text { HTZ }-170+\text { BDT }-7 \\
\text { HTZ }-170+\text { PCH }-2,5\end{array}$ & 28,5 \\
\hline Fertilizing and soil-cultivating & $\begin{array}{l}\text { HTZ -160 + } \\
\text { KTM 0822-324 + LDG-15 }\end{array}$ & $\begin{array}{l}\text { HTZ -170 + RUM-8 } \\
\text { HTZ - } 170+\text { LDG-15 }\end{array}$ & 38,0 \\
\hline Soil-cultivating and sowing & HTZ $-160+$ BP-8 +SUPN-12 & $\begin{array}{l}\text { HTZ }-170+\text { KPS- } 8 \\
\text { JUMZ }-80+\text { SUPN-8 }\end{array}$ & 40,0 \\
\hline Sowing & HTZ $-160+$ SN-75 + ZSZ-3,6 & HTZ $-170+$ SP-16 + 3C3-3,6 & 9,8 \\
\hline
\end{tabular}

One of the most important aspects of the practical operation of agricultural tractors is the calculation of their annual load and determining the required number. The solution to this issue for the South of Ukraine conducted by planning the use of tractors of the type HTZ-160 in technologies of cultivation of C. agricultural crops in the rotation short rotation (4 fields). On operations where the use of HTZ-160 from the point of view of the loading motor is impractical involved the use of a tractor of the class 1.4 (UMZ-80).

Because of its traction properties HTZ-160 relates to power tools power class 3 , when compiling the MTA on its basis focused on tools that are designed to work with a tractor $\mathrm{T}-150 \mathrm{~K}$. Removable productivity and fuel consumption of new units was accepted as normative [3] for a similar MTA-based power class 3 .

In accordance with process maps cultivation of $\mathrm{C}$. agricultural crops on normative data for each unit was determined indicators required to calculate the total cost. A variable parameter during the calculations was the area of field crop rotation. The minimum value was $\$ 300$ and the maximum is 3000 hectares initial data formed in three bases and processed on a PC using a specially developed program have been prepared.

On the basis of the estimated data built graphics machinery use for units on the basis of HTZ-160, determined their annual load and the desired quantity, labor costs and total costs, 
depending on the acreage of the adopted rotation.

For comparison, similar calculations were performed with the implementation of the adopted farming techniques $\mathrm{C}$. agricultural crops in the rotation short rotation units on the basis of serial universal plowing and cultivating tractor (UMZ-80) and total (T-150K) assignments.

For analysis was adopted of four-course rotation the following crops:

1) winter wheat;

2) peas;

3) sunflower;

4) South Africa.

It was established that for practical implementation of the adopted four field crop rotation on the area of 300 to 1000 ha the need for tractor HTZ-160 exceeds one. Its annual load varies from 350 to 1770 o'clock In the latter the distribution of this indicator during the year is even, and its value almost corresponds to the recommended conditions in the South of Ukraine (1700 hours) zonal load wheel power tools power class $3[3]$.

Using a square crop rotation over 2000 ha requires 2 tractors of the type HTZ-160 with an annual loading of each 1140 hours Normative level (1350 hours [8]) this indicator is provided on a surface of at least 1,000 hectares

For the implementation of this four field crop rotation units on the basis of the production of the energy resources necessary for the two tractors drawbar category 1,4 (UMZ-80) and 3 (T-150K). Introduction instead of one Horno-1 / $t$ tractor HTZ-170 to 1,000 ha leads to the reduction of labor costs by $28 \%$ of total costs up to $40 \%$, increase the annual load of new energy resources in comparison with the T-150 To $35 \%$.

\section{Conclusions}

Not always the use of foreign technology (and unnecessarily extended range) provides the desired efficiency of agricultural production. The use of machines on the basis of highly universal domestic energy resources, with advanced technology properties can provide high technical and economic results.

Naturally, the development of one or another of the combined unit on a "pull - push" cannot be implemented without taking into account the relevant theoretical knowledge. Indeed, in practice there are cases when front mounting machines or guns (especially energy-intensive) did not contribute to obtaining the desired effect. Improper mounting, instead of the desired paging caused unwanted discharge of the front (driven) wheels of the tractor, with the result that he lost control and stability of motion.

Practical implementation of new developments will largely depend on understanding Ukrainian agrarians' feasibility and benefits of their application.

\section{References}

[1] Binswanger, H P, "The economics of tractors in South Asia. Research Report". International Crops Research Institute for the Semi-Arid Tropics, 1978.

[2] M Mangahas, "Economic aspects of agrarian reform under the new society - Philippine", Review of Economics, 2012 pre.econ.upd.edu.ph

[3] Ramaswami, B; Shamiika, R; Chopra, S.D "Risk Management in Agriculture" Indian Statistical Institute, Planning Unit, 2005, Discussion Paper 03-08

[4] Patnaik, P, "Financial Liberalization and Credit Policy in Ramchandran, UK and Swaminathan”, 2005, Financial Liberalization and Rural Credit.

[5] Rangarajan C, "Report of the Committee on Financial Reforms" , 2010 http://www.nabard.org/pdf/report_financial/Full\%20Report.pd $\mathrm{f}$

[6] Rajeev, M; Ranade, R \& Deb, S "Why do poor farmers default less?: Case of Indian informal credit market A game theoretic exploration." , 2008 http://mpra.ub.uni-muenchen.de/768/01/MPRA_paper_768.pd f. Posted: 17 November 2006

[7] Sharma, H.R , "Economic conditions of agricultural labour households in 1990's: A state level analysis of wage earnings and indebtedness", The Indian Journal of Labour Economics, 2009, vol. 48 (2). pp. 425-436

[8] Shivappa, H "Agricultural Credit Utilization Pattern and its Repayment”, Indian Journal of Agricultural Economics, 2010, vol. 60 (3), summaries pp. 366-366.

[9] Yotopoulos, P.A. From stock to flow capital inputs for agricultural production functions: a micro-analytic approach. Journal of Farm Economics, v. 49, n. 2, p. 476-491, may 1967.

[10] Kravchuk V., Gritsishina, S., Koval M, "Modern trends in the design of agricultural machinery", 2004, Agricultural science, Kyiv .

[11] Nadykto V.T.,"Prospective directions of creating a composite and wide-coverage MTA", Tractors and agricultural machines, 2008, No. 3, pp..26-30.

[12] Nadykto V.T., Kryzhachkivsky M.L., Kyurchev V.M., Abdula S.L.,. "New mobile energy resources of Ukraine. The theoretical foundations for the use in agriculture", LLC "Publishing house MMD", 2005, Melitopol.

[13] Antoshenkov V.N. Antoshenkov R.V. "To the question of constructing a mathematical model of the combined machine-tractor unit", Tractor power in crop production, Agricultural: HSTOUCH, 2003. - Vol. 6, pp. 80-85. 